\title{
Holistic versus continuous grazing in Patagonia: A station-scale case study of plant and animal production ${ }^{\text {th }}$
}

\author{
Gabriel Oliva ${ }^{\mathrm{a}, \mathrm{c}, *}$, Daniela Ferrante ${ }^{\mathrm{a}, \mathrm{c}}$, Carla Cepeda ${ }^{\mathrm{a}}$, Gervasio Humano ${ }^{\mathrm{a}}$, Silvina Puig ${ }^{\mathrm{b}}$ \\ a INTA EEA Santa Cruz, Rio Gallegos, Santa Cruz, Argentina

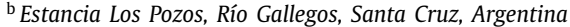 \\ ${ }^{c}$ UNPA National University of Austral Patagonia, Rio Gallegos, Santa Cruz, Argentina
}

\section{A R T I C L E I N F O}

\section{Article history:}

Received 20 March 2020

Revised 17 July 2020

Accepted 30 September 2020

\section{Keywords:}

Biodiversity

Grassland management

Grazing systems

Livestock

Rangelands

Rotational grazing

Semiarid lands

Sheep

\begin{abstract}
A B S T R A C T
We compared animal and vegetation responses of a 13 600-ha area under holistic grazing management (HGM) with a similar area under continuous grazing (CGM) in a Patagonian station. Limitations were a dry 2012-2016 experimental period, poorer soils, and grazing of native guanacos (Lama guanicoe) in the HGM area. Forage standing crop in this area before the experience was lower and remained so during the study: (194 $\pm 31 \mathrm{HGM}$ vs. $244 \pm 33 \mathrm{~kg}$ dry matter ha ${ }^{-1}$ CGM). Six monitoring sites showed similar and remarkable (though mostly nonsignificant) vegetation improvements in total cover (10.6\% HGM vs. $10.9 \%$ CGM) and cover of short palatable grasses (21.4\% vs. $23.9 \%$, respectively). Species richness showed small changes ( -1 vs. $-6 \%$ ), bare soil interpatches decreased ( -11.9 vs. $-5.4 \%$ ), and land function indicators of Stability (5.4\% vs. $9.9 \%$ ), Infiltration (12.4\% vs. $12.0 \%$ ), and Nutrient recycling (4.2\% vs. $20.6 \%$ ) increased. Tussock cover changed significantly with grazing management, as it decreased -6\% (ns) in HGM and grew 42\% $(P=0.03)$ under CGM, probably due to coarse tussock forage consumption in HGM. Sheep under HGM were $15 \%$ lighter $\left(43.9 \pm 0.5 \mathrm{HGM}\right.$ vs. $\left.51.7 \pm 0.5 \mathrm{~kg} \cdot \mathrm{ewe}^{-1} \mathrm{CGM} P<0.001\right)$, ewes scored $28 \%$ lower body condition ( 1.60 vs. $2.25, P<0.001)$, and lambing rates were $36 \%$ lower $(48.3 \pm 2.1 \%$ vs. $74.2 \pm$ 1.9\%). Rotation ended in 2015 as a consequence of low lambing rates, and sheep body condition and reproductive rates recovered to similar values in both areas. Positive vegetation changes in both areas may be driven by residual effects of destocking 3 decades ago and show that improvement is possible using moderate stocking rates. Although it could be argued that rest periods of HGM may be positive in the long term, its negative effects on animal production should be addressed, and fast regeneration using intense management in these severely restricted habitats should not be expected. Slow, persistent progress under careful management seems achievable under both grazing systems.
\end{abstract}

(c) 2020 The Society for Range Management. Published by Elsevier Inc. All rights reserved.

\section{Introduction}

Patagonia, with $780000 \mathrm{~km}^{2}$ is one of the remaining natural rangelands in the world, but about a third of the region is degraded, probably due to poor grazing management. Sheep were introduced in these semiarid lands at the turn of the 19th century and have been managed under continuous grazing with no forage supplements ever since (Cibils and Borrelli 2005). High stocking rates were common at early stages of domestic grazing and livestock inventories peaked in 1952 with 21.2 million sheep. As a result of reduced forage production, stations destocked or were abandoned (Golluscio et al. 1998).

\footnotetext{
th This study was financed by INTA project PNPA 1126074.

* Correspondence. Gabriel Oliva. INTA EEA Santa Cruz. Mahatma Gandhi 1322. 9400 Rio Gallegos. Santa Cruz. Argentina

E-mail address: oliva.gabriel@inta.gob.ar (G. Oliva).
}

Most researchers consider that overgrazing has been the main cause of land degradation in arid lands (Le Houérou 1996; Soriano 1956). In this view, adjusting stocking rates to grazing capacity should be enough to ensure rangeland regeneration. Some authors point out, nevertheless, that the main cause of degradation is not stocking rate but continuous grazing itself because it promotes selectivity and generates pressure on certain landscapes, communities, and species (Teague et al. 2011). They argue that a different management, with grouped animals that rotate between paddocks generating intense grazing periods, would reduce selectivity and make a better resource use (Merrill 1954; Voisin 1959; Teague et al. 2008). Rotational grazing studies worldwide reviewed by Holechek et al. (2000) and Briske et al. (2008) and a few grazing studies in Patagonia (Anchorena et al. 2001; Borrelli 2001; Fariña et al. 2018; Paruelo et al. 1992) have shown little evidence of the alleged increased production of these systems when compared with continuous grazing. Teague et al. (2008) pointed out, 
however, that these reviews mostly encompass fixed rotational systems in small plots that are rigid in relation to station-scale operations. In comparison, holistic grazing management (HGM) that uses short high-intensity grazing periods combined with long rest intervals would provide the required flexibility and obtain better results (Savory 1991; Savory 2018; Savory and Butterfield 1999; Savory and Parson 1980). In this system, animals generate "mob-grazing" effects that allegedly break ground crusts, allowing for increased water and nutrient flow while presumably sowing seeds and adding fertilizer through dung and urine. McCosker (2000)summarized the principles of HGM as 1) rest periods to suit plant growth rate; 2) stocking rates should match grazing capacity; 3) grazing planning, monitoring, and management; 4) short grazing periods in order to increase animal performance; 5) maximum stock density applied for a short time period; 6) diversity of plants and animals to improve ecological health; and 7) large mob size to make herding easier. HGM has been practiced in Zimbabwe (Abel and Blaikie 1989), the United States (Stinner et al. 1997), South Africa (Du Toit et al. 2009), Botswana, Namibia (McCosker 2000), Australia (Massy 2014), Argentina (Borrelli 2016), and other countries such as Mexico and Mali (Roncoli et al. 2007).

This paper analyzes a station-scale case study of HGM use in Los Pozos, a Patagonian sheep station that has been under continuous grazing since 1885 . The Halliday family own this station and decided in 1989 to change the traditional management that used high, fixed-animal numbers and adopt a flexible stocking strategy that kept numbers approximately $20 \%$ below the annual estimated grazing capacity. This management helped to reduce range deterioration, as standing forage crop and residual stubble height of key species showed a 20 -yr stable trend. Although no detailed vegetation and soils monitoring was available at this stage, vegetation visually gained in cover, diversity, and frequency of decreaser species in comparison with neighboring stations (Oliva personal observation). The station with smaller flocks continued to produce lambs and ewes at historical numbers, but wool production decreased moderately (Oliva et al. 2012). During 2012 and 2016, in an attempt to further enhance forage production, half of the station was converted to HGM.

The objective of this study was to compare vegetation and animal production of the area converted to HGM in relation to the one that remained under CGM. The expectations were that HGM would induce an increase in total vegetation and palatable species cover (Teague et al. 2011), plant biodiversity (Stinner et al. 1997), and nutrient cycling, stability, and infiltration (Savory 2018). A moderate, initial reduction in animal production was expected due to lower quality forage consumption (Teague et al. 2013), but this effect would be compensated as sheep changed their diets, got used to rotation, and got the opportunity to consume plants that have regrown after being grazed (Provenza 2003). Nutrient cycling in the rangeland was expected to improve, and an increased grazing capacity would eventually compensate any animal production losses (Savory 2018).

\section{Methods}

Los Pozos occupies 27200 ha in the Dry Magellan Steppe (Fig. 1), $30 \mathrm{~km} \mathrm{~N}$ of Río Gallegos, Santa Cruz, Argentina $\left(69^{\circ} 19^{\prime} \mathrm{W}\right.$, $\left.51^{\circ} 29^{\prime} \mathrm{S}\right), 150 \mathrm{~m}$ above sea level with a rainfall of $240 \mathrm{~mm}$ (1930-2019), $7.2^{\circ} \mathrm{C}$ mean annual temperature, and strong westerly winds. Soils were Xeric Natrargides in the north part of the station and Aridic Argiustols in the south, covered by tussock grass steppes of Festuca gracillima with short grasses (Poa spiciformis), graminoids (Carex spp.), forbs, and dwarf, prostrate shrubs (Nardophyllum bryoides) (Faggi and Roig 1985). Annual aboveground primary production is $980 \mathrm{~kg}$ dry matter (DM) ha ${ }^{-1}$ with $286 \mathrm{~kg} \mathrm{DM} \mathrm{ha}^{-1}$ of short grasses and forbs (Cibils et al. 2005).
Mean annual rainfall in the area between 1990 and 2018 was $240 \mathrm{~mm}$, with a slight, nonsignificant temporal negative trend (Fig. 2). Yr 2002 and 2003 were exceptionally rainy and 1995, 1999, and 2016 were dry. This last year marked the end of a dry spell that started in 2012 and encompassed the grazing trial.

Short grasses, graminoids, and forbs, which constitute $73 \%$ of the sheep diets in summer (Posse et al. 1996), were harvested during peak herbage mass in order to estimate forage on offer (Borrelli and Oliva 2001), as has been done yearly in Los Pozos since 1990 (Oliva et al. 2012). Two or three permanent sites (see Fig. 1) in each paddock were sampled with $0.2-\mathrm{m}^{2}$ quadrats ( 9 or 12 quadrats per permanent site), and forage was clipped to $1-\mathrm{cm}$ height. Samples were dried, weighted, and considered consumable forage. Given that short grasses, graminoids, and forbs represent about $29 \%$ of the aboveground net primary production of the Magellan Steppe (Cibils et al. 2005), these assessments are roughly comparable with those obtained with methodologies, such as double sampling, pastoral value, or range condition matrix, which include in semiarid regions a utilization factor of about 30\% (Holechek 1988). Total consumable forage was estimated on the basis of paddock size and grazing capacity calculated by dividing this total offer by $513 \mathrm{~kg}$ of DM, the estimated ewe equivalent (EE).

The EE is the annual 55\% digestibility-forage consumption of a $49-\mathrm{kg}$ ewe that raises a $20-\mathrm{kg}$ lamb with $100 \mathrm{~d}$ of lactation (Borrelli 2001). This unit is nearly equal to New Zealand's EE, 1.54 dry sheep units used in Australia or 0.12 animal unit yr used in the United States (SRM 1989).

Five paddocks totaling 13722 ha in the north (mean size 2 700 ha) were converted to HGM between 2012 and 2015 (see Fig. 1). Grazing planning was done by OVIS consultants, the local representative of Savory Institute hub, jointly with the producer's family twice yearly in December and March. Mean grazing ca-

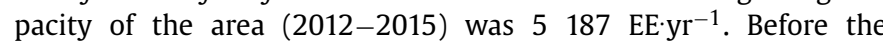
experiment (2000-2012) the area had been grazed with a flock of 2478 ewes, and 1355 hoggets ( 3562 EEs) were assigned to HGM during 2012-2013, but in view of low lambing rates only 2472 ewes were allocated there during the 2014-2015 period. Sheep were concentrated in a single group and rotated between paddocks, generating 2-3 annual grazing periods in the first $2 \mathrm{yr}$ with $70-140 \mathrm{~d}$ of recovery (Fig. 3). In the third yr, plants were not visually perceived to be regrowing adequately and only one grazing pulse was planned in the growth season with a 200-d rest period because HGM was replaced by CGM at the beginning of spring. Mean duration of grazing periods was $30 \mathrm{~d}$, with a stocking rate of $1.1 \mathrm{EEs} \cdot \mathrm{ha}^{-1}$ (see Fig. 3). In order to ensure adequate water supply, two additional water holes were bored and movable pumps with water tanks were used during the study.

Five paddocks totaling 12794 ha south of the station (mean size 2132 ha) remained under CGM as a control group (see Fig. 1). Total grazing capacity (2012-2015) of this area was 6090 EEs. A flock of 4566 ewes and a small number of rams and wethers were distributed according to yearly grazing capacity of each paddock, as had been done in Los Pozos since 1989.

Guanacos (Lama guanicoe), a native camelid, shared the grazing area with sheep in HGM area. In the 1990s they were limited to a small 300-animal group in the north area (Halliday personal communication), far away from the homestead. Over the past 2 decades, reduced hunting triggered an increase of population across the region (Oliva et al. 2019b), as well as in Los Pozos, where populations grew but still remained mostly in the north. Their numbers were assessed using 16 terrestrial transects of variable length, totaling $70 \mathrm{~km}$. Guanaco groups were spotted using a Bushnell $10 \times 25,1000$ laser telemeter, and data were processed with Distance Sampling 7.0 software (Buckland et al. 2005). Density analysis was stratified by date and used global density 

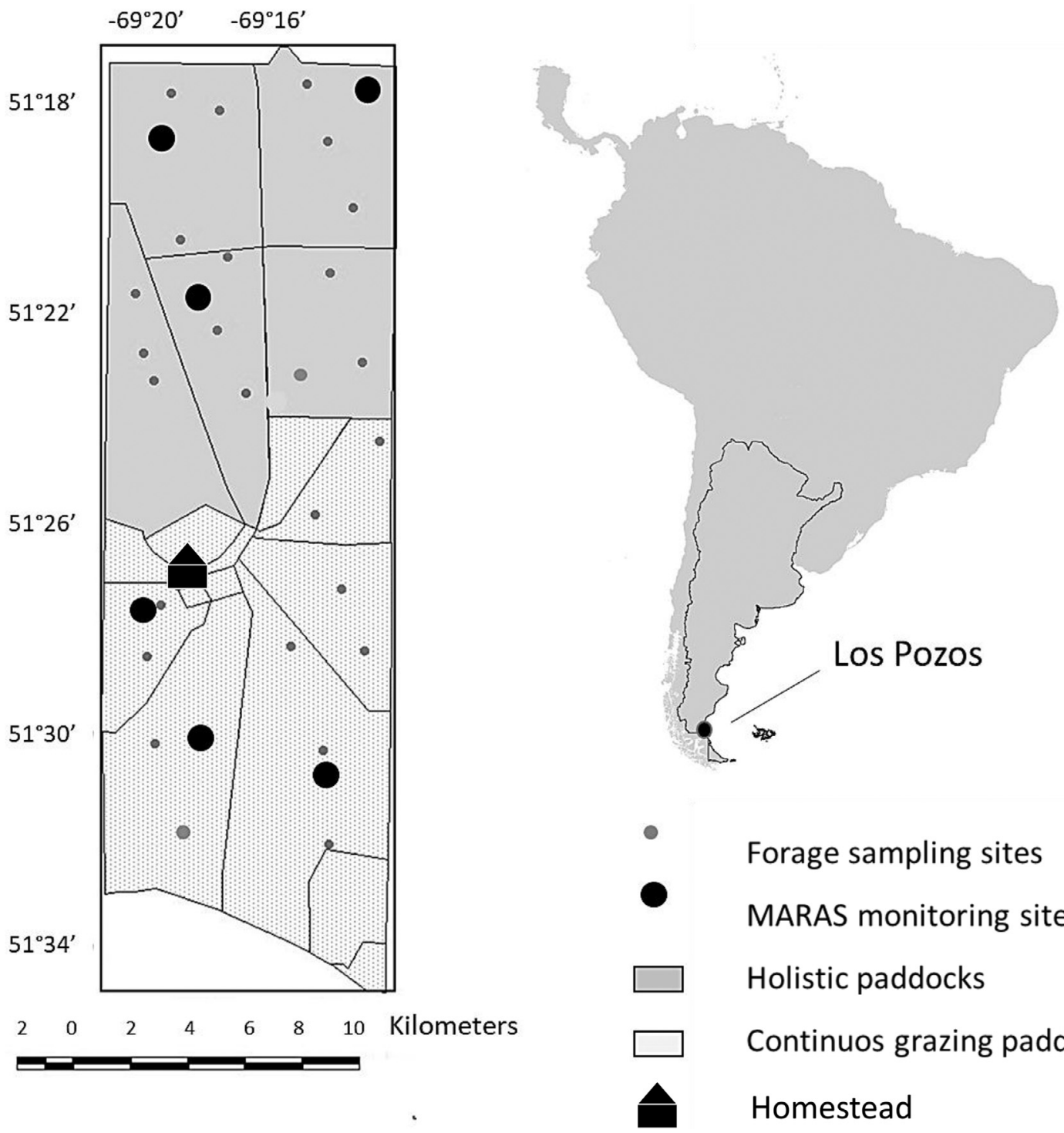

Forage sampling sites

MARAS monitoring sites

Holistic paddocks

Continuos grazing paddocks

Homestead

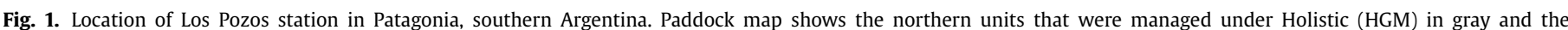

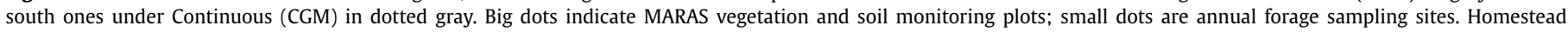
is marked in the center of the station.

Table 1

Date of guanaco assessments, density, standard deviation, and estimated $\mathrm{N}$ (distance sampling) for northern area of Los Pozos.

\begin{tabular}{llll}
\hline Date & $\begin{array}{l}\text { Density } \\
\text { guanacos.km }\end{array}$ & $\begin{array}{l}\text { Standard } \\
\text { deviation }\end{array}$ & $\begin{array}{l}\text { Estimated N (HGM } \\
\text { paddocks) }\end{array}$ \\
\hline May 2014 & 6.6 & 1 & 1789 \\
September 2014 & 7.4 & 1.1 & 2023 \\
January 2015 & 8.7 & 1.3 & 2358 \\
October 2015 & 13 & 2 & 3539 \\
January 2016 & 12.4 & 1.9 & 3372 \\
Mean & 9.6 & 1.5 & 2616 \\
\hline
\end{tabular}

with a half-normal detectability function and cosine expansion series. Estimations during the grazing management study were performed in May 2014 and January 2015 and showed that 7.5 individuals $\cdot \mathrm{km}^{-2}$, equivalent to 2056 guanacos, grazed the HGM area. Guanaco populations continued to grow after the north area returned to CGM in September 2015, reaching 12.7 individuals. $\mathrm{km}^{-2}$ between October 2015 and January 2016, with an estimated population of 3455 guanacos (see Table 1).
Vegetation and soil monitoring plots were set up in three different paddocks (see Fig. 1) under HGM and three paddocks under CGM following the MARAS protocol (Oliva et al. 2019a). Vegetation cover was analyzed in 500-point line transects, patches and interpatches (bare soil areas) were identified in a 50-m Canfield line, and land function analysis (LFA) was visually analyzed in 10 plots assessing 1) aerial cover for rain interception; 2) basal cover of patches; 3 ) litter cover, origin, and degree of incorporation; 4) cryptogam cover; 5) soil erosion; 6) deposited materials; 7) micro topography; 8) soil crust type and disturbance; 9) surface crust resistance; and 10) slake test, which estimates integrity of soil aggregates in water. Indicators were combined to estimate land function indices of stability, nutrient recycling, and infiltration (Tongway 1994). Two monitoring sites (one in north and one in south area) were installed in 2009 and the rest in 2013. All were evaluated in autumn of 2018, with a mean period of reassessment of $5.8 \mathrm{yr}$ in HGM and $5.0 \mathrm{yr}$ in CGM.

One-hundred ewes from the HGM flock and a similar number from a CGM paddock were weighted and assessed for body condition scores (Russel et al. 1969). 


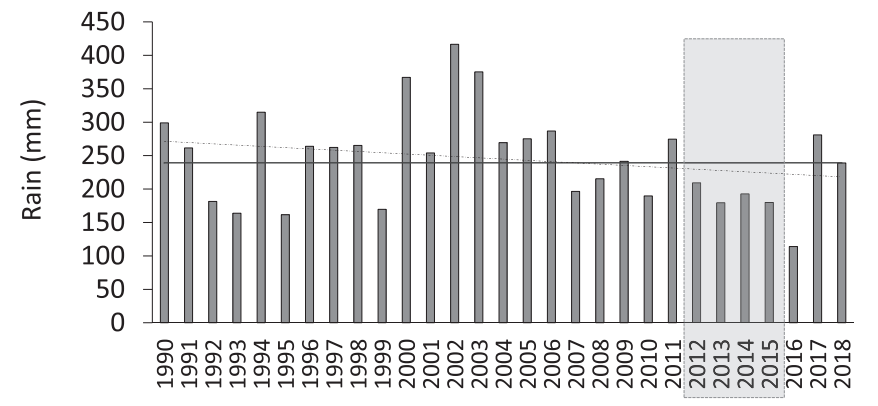

$\square$ Rainfall - Mean -.-.- Linear regression

Fig. 2. Rainfall (bars) in Rio Gallegos airport meteorological station, $20 \mathrm{~km}$ from Los Pozos, between 1990 and 2018. Dotted line at $239 \mathrm{~mm}$ is the mean value of this period, and full line is a linear regression $\left(\mathrm{y}=-1905 \times+273,4 ; R^{2}=0.05 ; P=0.229\right.$ ns).

Yearly lambing rate (\%) was estimated as the number of lambs marked (January) versus ewes bred (May of previous year).

Five paddocks under HGM and five under CGM were compared, but given the spatial segregation they did not constitute true replications. The differences are presented using descriptive statistics and cannot undoubtedly be attributed to the grazing system but also to geographic areas. Differences in cover (final-initial) between reassessed monitoring plots within each grazing treatment were examined using the paired "t"” test $(n=3)$. Animal live weight differences were analyzed with 1-way analysis of variance (ANOVA) $(n=100)$. Body condition scoring is a categorical variable, and differences between treatments were assessed using the

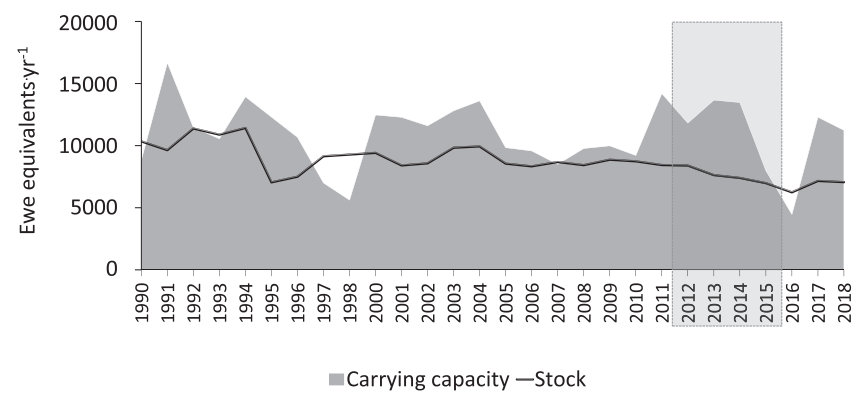

Fig. 4. Total grazing capacity based on annual field estimations of forage availability (gray area) and station stocking rate (line) in ewe equivalents $\mathrm{yr}^{-1}$ in Los Pozos station from 1990 to 2018. Shaded area shows the grazing systems trial period.

Kruskal-Wallis test. All tests were run using INFOSTAT (Di Rienzo et al. 2011) and a significance level of $P<0.05$.

\section{Results}

Mean stocking in the $1990-2017$ period was $8569 \mathrm{EEs} \cdot \mathrm{yr}^{-1}$, $20 \%$ below the estimated grazing capacity (10 $721 \mathrm{EEs} \cdot \mathrm{yr}^{-1}$, Fig. 4). Overgrazing only took place in extraordinarily dry periods between 1999 and 2000 and 2015 and 2016.

Before the experience (1990-2011), forage herbage availability (which determines grazing capacity per ha) was lower in the north area that was used in the HGM experience in relation to south portion of the station that remained under CGM: 163.3 (8.5 SE) kg $\mathrm{DM} \cdot \mathrm{ha}^{-1}$ versus 240.5 (15.5) $\mathrm{kg} \mathrm{DM} \cdot \mathrm{ha}^{-1}$, respectively. During the grazing experience, forage availability in a per-ha basis continued being lower in the north HGM area (194 [31 SE] kg DM $\cdot \mathrm{ha}^{-1}$ ) in

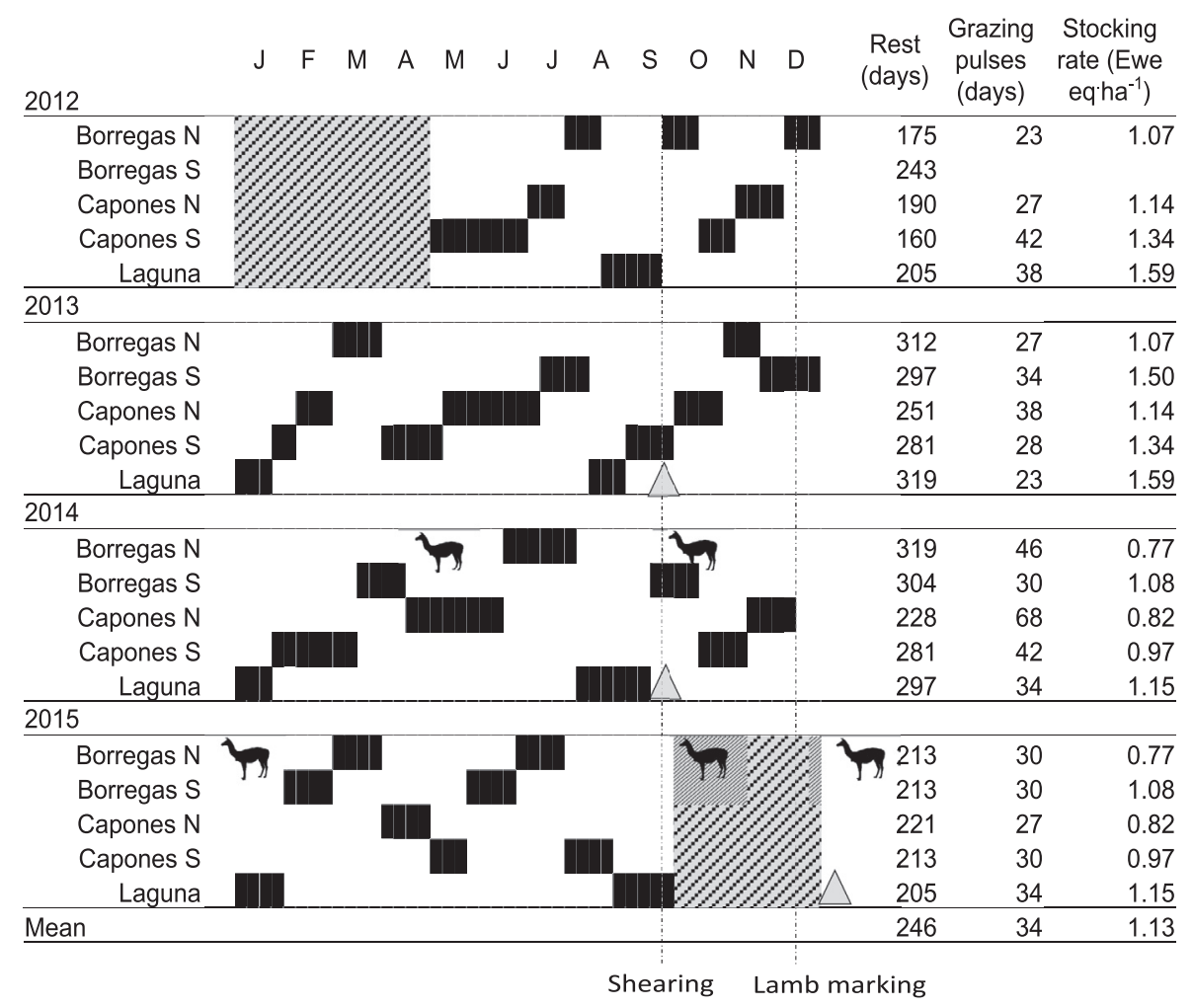

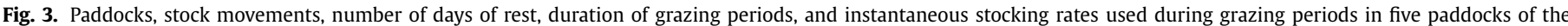

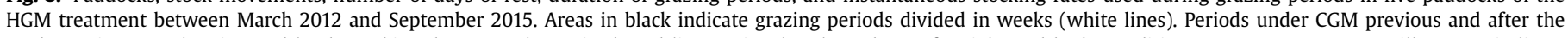

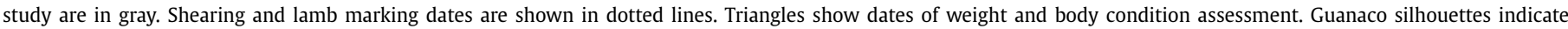
dates of guanaco evaluation. 

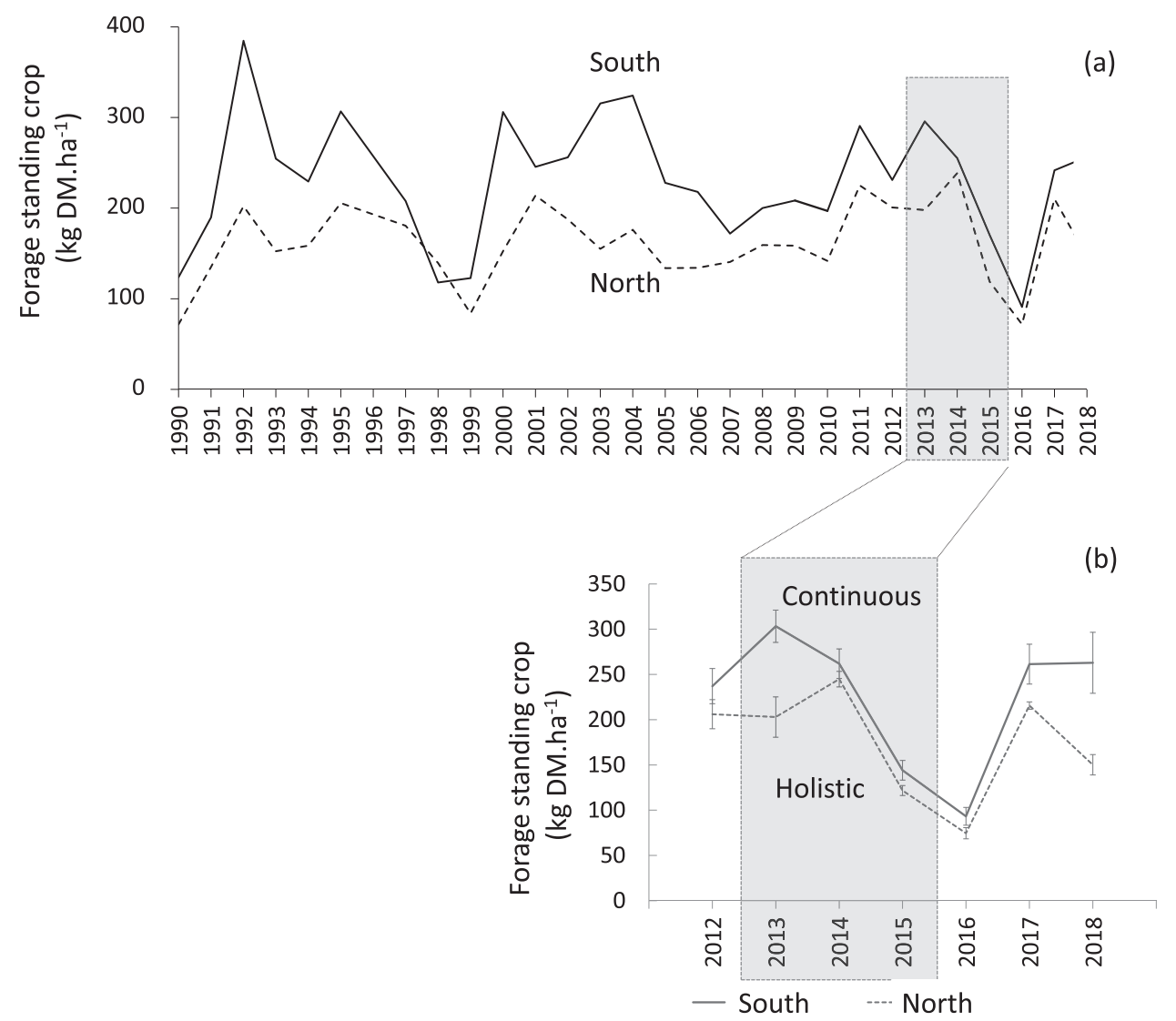

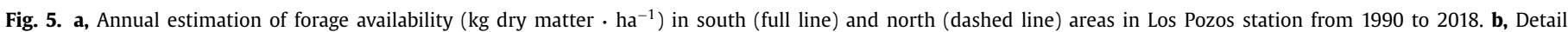
of 2012-2018 period including the grazing systems trial (shaded), in which the north area was subjected to HGM. Bars represent standard error of the means.

relation to the south, CGM one (244 [33] $\left.\mathrm{kg} \mathrm{DM} \cdot \mathrm{ha}^{-1}\right)$. Between 2014 and 2016, drought intensified and standing crop fell to similar values in both treatments. All the stations recovered in a similar way after the grazing systems trial with 2017 rains (Fig. 5), but in 2018 north and south returned to historical differences in forage standing crop.

Total cover increase was similar under HGM (10.6\%) and CGM (10.9\%), but this increment was only significant under CGM $(P=0.049$; paired " $T$ " test). Cover of plant functional groups of short palatable grasses (21.4 HGM vs. 23.9\% CGM) and dwarf shrubs (50.2\% and $19.9 \%$, respectively) increased, but these increments were not significant in any case. Instead, in the Tussock functional group the response to grazing treatments differed, as cover decreased nonsignificantly between time periods under HGM $(-5.6 \% \mathrm{~ns})$ and increased significantly under CGM $(42.2 \% P=0.026)$ (Fig. 6). P. spiciformis, the key forage species showed remarkable $60 \%$ and $48 \%$ increases in CGM and HGM, respectively (data not shown), although both these differences were nonsignificant. Diversity measured as plant species richness showed small and nonsignificant changes ( -1 HGM vs. $-6 \%$ CGM). Bare soil interpatches decreased (-11.9 HGM vs. $-5.4 \%$ CGM), and the size of vegetation patches increased clearly (55.3 HGM vs. 60.3\% CGM data not shown), but these differences were nonsignificant. Land function indicators (LFA) of stability (5.4\% vs. $9.9 \%)$, infiltration $(12.4 \%$ vs. $12.0 \%)$, and nutrient recycling (4.2\% vs. $20.6 \%)$ increased in a similar nonsignificant way in both treatments (see Fig. 6).

Animals were significantly lighter during 2013 and 2014 under HGM in relation to those under CGM: 43.9 (0.5 SE) versus 51.7 (0.5) kg.ewe ${ }^{-1}$, respectively $(P<0.05)$ (Fig. 7). Body condition scores were also lower in HGM than in CGM at both sam- pling dates: 1.60 versus 2.25 , respectively (Kruskal-Wallis test; $P$ $<0.001$ ). In 2016, after the study ended, animals of the north area (former HGM) were still lighter but their body condition increased and scored slightly better than those of the south one (always under CGM): 2.79 versus 2.67, respectively (Kruskal-Wallis test; $P=0.028$ ) (see Fig. 7).

Given that stocking rates were adjusted to forage availability, each ewe had a similar forage allowance and obtained similar lamb marking rates before the grazing management study (1990-2011) north 89.3\% (2.1 Standard Error) and south 89.5\% (1.9) (Fig. 8). Production per ha in this period was, on the other hand, only a third in the north area of the farm in relation to the south: 0.10 \pm 0.01 versus $0.30 \pm 0.01$ lambs $\cdot \mathrm{ha}^{-1} \cdot \mathrm{yr}^{-1}$, respectively. During the grazing trial, lamb marking rates remained similar to historical values during 2012 (but fell sharply in 2013-2014 to lower values under HGM (48.3\% [2.1] HGM vs. 74.2\% (1.9) CGM). Lamb production during this period fell to 0.06 (0.02) HGM vs. 0.23 (0.03) lambs $\cdot \mathrm{ha}^{-1} \cdot \mathrm{yr}^{-1} \mathrm{CGM}$. Lambing rates increased in the two areas after the rotation ended between 2015 and 2016 to $67.4 \%$ (5.6) in the north (previously HGM) and $70.7 \%$ (3.7) in the south (that was always under CGM), even when the animal stock decreased less than the grazing capacity during the worst part of the drought (see Fig. 4). During 2017-2018 drought receded, forage DM reestablished, and both areas returned to previous values of lambing rates: $82.7 \%$ (5.3) in the north area and $96.0 \%(7.5)$ in the south area.

\section{Discussion}

This HGM study was generated by producers with flexible management at a station scale, and planning was led by the local hub 


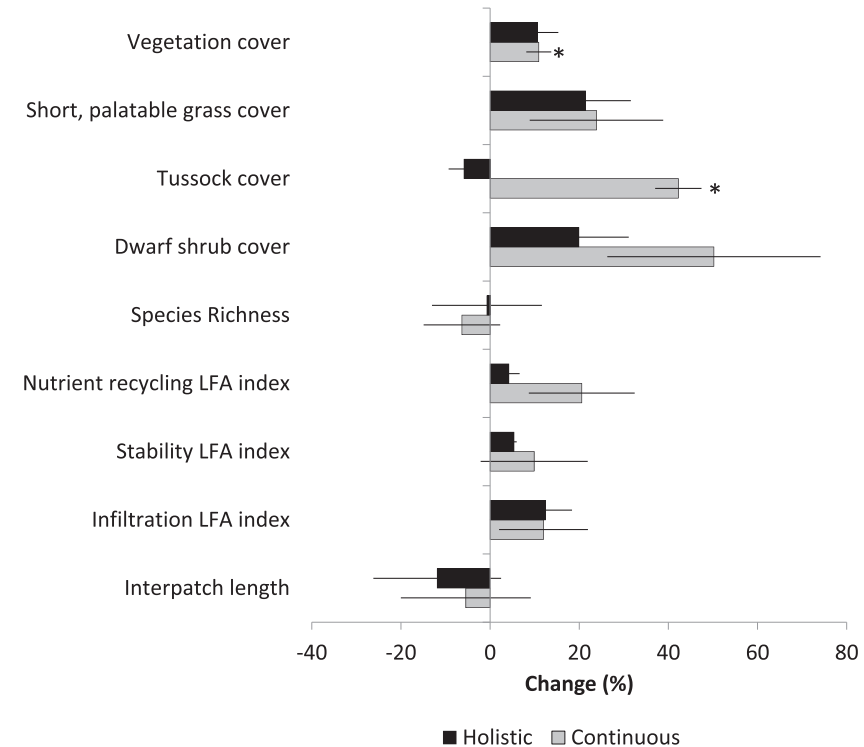

Fig. 6. Percent change (Final-Initial/Initial-100) of total vegetation cover, short palatable grasses, tussocks, dwarf shrubs, plant species richness ( $n^{\circ}$ of species), land function indicator indexes of nutrient recycling, stability, infiltration, and interpatch (bare soil areas) length in MARAS monitoring plots in HGM (black) and CGM (gray) paddocks. Lines represent standard error of the mean. Asterisks indicate significant change (initial vs. final).

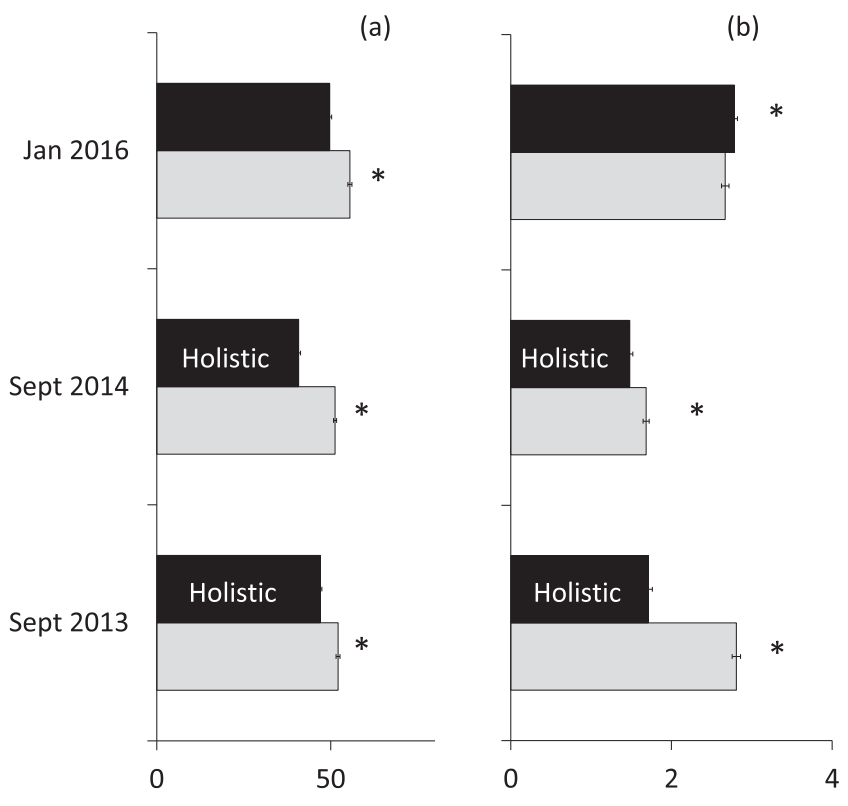

Liveweight $(\mathrm{kg}) \quad$ Body condition scoring

Fig. 7. a, Live weight in $\mathrm{kg}$ and $\mathbf{b}$, body condition scoring for 100 ewes from north (black) and south (gray) areas of Los Pozos in 3 dates. Sheep in north area were under HGM during 2013-2014, and the rest were under CGM. Asterisks indicate significant differences $P<0.05$ for analysis of variance (live weight) or Kruskal-Wallis (body condition) analysis. Lines indicate standard errors.

of Savory Institute. It is not a true experiment because of its unreplicated nature, but this is common to most of the previous analysis of HGM (Peel and Stalmans 2018; Teague et al. 2011; Weber and Gokhale 2011). As Savory (2013) himself points out, the only possible outcome of these studies are the "results obtained." As an advantage, areas under different grazing regimes shared managers and had similar livestock, something that is not usual in adja-

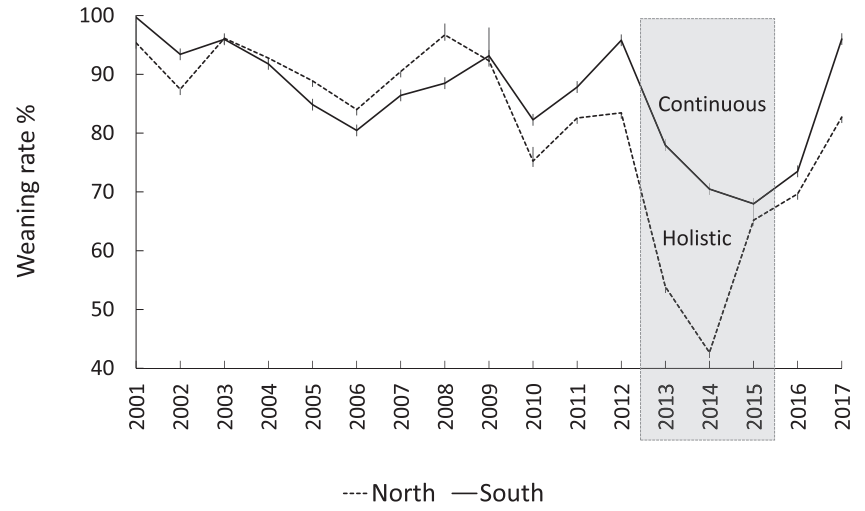

Fig. 8. Lambing rates \% (lambs obtained/ewes mated) between 2001 and 2017 in north (dashed line) and south (line) areas in Los Pozos. Vertical lines are standard errors of the mean. During 2012-Sept 2015 (gray area), HGM was applied in the north, while the south remained under CGM all the time.

cent station comparisons (Earl and Jones 1996; Jacobo et al. 2006; Teague et al. 2008). Several limitations can be on the other hand pointed out: The experimental period was very dry. The north area shows Xeric Natrargides with shallower sandy A horizon in relation to the more productive Aridic Argiustols, which show a deeper, more fertile topsoil that dominates in the south. The area was selected to be subjected to HGM, expecting that it would enhance forage production. Guanaco grazing also interfered with rest periods, which are the main strategy of HGM in order to improve rangelands. Grazing periods were relatively long and not as intense as recommended (McCosker 2000; Teague et al. 2008) because only five paddocks were available to plan the movements. Finally, HGM was not compared with traditional CGM but with improved CGM, as Los Pozos had previously kept stocking rates well below grazing capacity for $25 \mathrm{yr}$ (see Fig. 4). This set high initial standards of individual animal production, vegetation cover, and biodiversity from which the HGM should have improved.

\section{Vegetation and Soil Responses}

Some holistic and rotational GM applications have reported increases in forage productivity in relation to CGM (Cumming 1989; Earl and Jones 1996; Goodloe 1969; Ferguson et al. 2013; Norton 2003), although reviews by Briske et al. (2008), Holechek et al. (2000), and Hawkins (2016) found no differences in most cases or even showed an inverse trend. In Los Pozos standing crop remained comparatively lower under HGM in 2013, but as drought increased, both treatments reached values only comparable with the 1989 and 1999 droughts (see Fig. 5). The entire station recovered vigorously when rains returned in 2017, but north and south areas were back to their initial differences in 2018, a close-tonormal rainfall year, showing no obvious residual effects of HGM.

The setup of vegetation monitoring plots was not timely because two of them were installed previously and the rest once the grazing systems experience was already in place. Additionally reevaluation was postponed until the drought receded, implying that HGM sites were also subject to a considerable CGM period. The design was nevertheless similar for both grazing systems, and it aimed at detecting long-term change in "slow" (Reynolds et al. 2007) variables that should not be erased by a period of continuous grazing in these perennial-dominated rangelands. A general and remarkable vegetation improvement was registered in both grazing systems: cover grew 10-35\%, bare soil and standing dead decreased, and key forage species increased: 49\% under HGM and $60 \%$ under CGM (Fig. 6). The general trend may be a residual effect caused by the 50\% destocking 3 decades ago (Oliva et al. 2012). 
Moderate stocking rates under CGM have induced similar longlasting increases in vegetation cover in semiarid regions (Naeth et al. 1991; Noy-Meir et al. 1989), including the Magellan Steppe, where Oliva et al. (1998) documented increases of 30\% vegetation cover after $5 \mathrm{yr}$ of CGM with $0.20 \mathrm{EEs} \cdot \mathrm{ha}^{-1} \cdot \mathrm{yr}^{-1}$.

One of the two statistically significant changes in the MARAS monitoring plots was observed in tussock cover that increased significantly under CGM and decreased nonsignificantly under HGM (see Fig. 6), and this reduction should be monitored in the future. F. gracillima is the dominant tussock with $22 \%$ cover, but it produces poor-quality forage and accumulates senescent foliage. Posse et al. (1996) found that sheep under CGM only included about 4\% of tussocks in their diets and preferred instead short grasses such as $P$. spiciformis that, in comparison, offers $7-8 \%$ crude protein and $62 \%$ digestibility in a whole-plant diet analysis versus $2 \%$ of crude protein content and $40 \%$ digestibility for F. gracillima (Lara and Cruz 1987).

HGM uses short grazing periods to force animals to graze items of lesser quality (Teague et al. 2011) removing dead, oxidized materials that shade growth points and may, in view of Savory (2018), actually kill plants. Grazing is expected to release trapped nutrients and induce regrowth, but $F$. gracillima was probably unable to activate meristems after grazing as in other perennial grasses, such as Festuca pallescens in Patagonia (Bertiller and Defossé 1990) and Agropyron spicatum in the United States (Caldwell et al. 1981). F. gracillima is sensitive to grazing (Faggi 1985), and demographic models show that under CGM at high stocking rates their populations may disappear in the midterm (Oliva et al. 2005), mainly because they induce tussock subdivision and tiller mortality in dry years.

Exclosures and rest periods in arid lands usually increase diversity (Oba et al. 2001), and Stinner et al. (1997) found that 95\% of the farmers who applied HGM perceived increases in biodiversity. Furthermore, in a neighboring site of the Magellan steppe, grazing exclusion has induced a 30\% increase in richness from 16 to 21 species in a 5-yr period (Oliva et al. 1998). However, no changes in species richness (see Fig. 6) or Shannon index (data not shown) were observed in this study. Nevertheless, this lack of CGM versus HGM differences in plant diversity may be attributed to the short duration of HGM implementation ( $2.5 \mathrm{yr}$ ) and/or to the favorable starting point: 26 species in the south and 24 in the north area.

In the Magellan Steppe, vegetation is structured in a heterogeneous pattern (Aguiar and Sala 1999) with patches that act as "sinks" of resources that may be disorganized by grazing (Bisigato and Bertiller 1997). HGM has induced decreases in bare soil in relation to CGM in some studies (Teague et al. 2011), but the opposite trends in others (Fariña et al. 2018). No significant treatment effects were detected in Los Pozos, as monitoring plots started with small interpatches $(25 \mathrm{~cm}$ in north and $35 \mathrm{~cm}$ in south) that decreased in both treatments (see Fig. 6). At the same time, vegetated patches increased markedly ( $+58 \%$; data not shown).

Restoring land function is another objective of HGM, as grazing periods are supposed to break soil crusts, increase infiltration, mobilize nutrients, and favor stability (Savory 2018). In this study, land function indexes for nutrient recycling, stability, and infiltration increased $8-19 \%$ (see Fig. 6), but no treatment differences were detected.

\section{Animal Responses}

Sheep under HGM weighed $8 \mathrm{~kg}$ (15\%) less and scored $28 \%$ lower body condition (see Fig. 7). The decrease in animal individual production is common under high stock density (Teague et al. 2008), even if yearly stocking rate is kept constant, but should be transient until animals adapt and expand the menu of species they consume, a process that Provenza (2003) estimates could take up to $3 \mathrm{yr}$. In the Los Pozos this adaptation was not observed, and differences in weight and body conditions between grazing systems persisted even when yearly stocking rates were similarly adjusted to forage availability. Recommended forage allowance in the Magellan Steppe is $500 \mathrm{~kg} \mathrm{DM}{ }^{-1} \cdot \mathrm{yr}^{-1} \cdot \mathrm{ewe}^{-1}$ (Borrelli 2001), and during 2014-2015 paddocks under CGM were grazed using 4 $566 \mathrm{EEs}$, with a forage allowance of $540 \mathrm{~kg} \mathrm{DM}{ }^{-1} \cdot \mathrm{yr}^{-1} \cdot \mathrm{ewe}^{-1}$. In turn, HGM used 2472 EEs, with a forage allowance of $798 \mathrm{~kg}$ $\mathrm{DM}^{-1} \cdot \mathrm{yr}^{-1}$. ewe $\mathrm{e}^{-1}$. HGM area had approximately 2057 guanacos (=3 085 EEs; Sarasqueta 2001) leading to a total stocking of 5557 EEs, only somewhat higher than grazing capacity, estimated at 5 187 EEs.

Animal condition may have suffered due to planning decisions on winter movements as HGM flocks shifted between great paddocks in a 13000 -ha area, but this is most probably due to poor diet quality as shown in other studies (Heitschmidt and Taylor Jr 1991). Differences of animal body condition and live weight decreased or reversed (see Fig. 7) when the north area returned to CGM in 2016, in the worst part of the 2012-2016 drought and with guanaco numbers that continued to grow from 2056 (mean 20142015) to 3455 (mean October 2015-January 2016).

Poor body condition may explain 25\% loss of lambs in HGM in relation to CGM (Fig. 8). Ewe body condition is known to influence lamb weight (Iglesias et al. 2005) because lambing takes place with low temperatures (Coronato 1999) and ewes rely on body reserves for lactation. Poor body conditions have generated great winter mortalities in other HGM experiences in Patagonia (Cibils and Fernández 2014). In addition, lambs may die if they are detached from their mothers during stock movements. Lamb production during the drought and HGM fell to half the historical level in the north paddock reaching 0.05 lambs.ha ${ }^{-1} \mathrm{yr}^{-1}$ in 2014, and in view of that the drought persisted. In September 2015 producers decided to stop the rotation and continue with CGM with sheep distributed in the paddocks according to their grazing capacity.

\section{Implications}

In extensive dryland grazing systems, adequate stocking rate and rest are two of the few range management tools available (Heady and Child 1994). HGM generated rest periods in rangelands that have probably been grazed for over a century with good results, but the response was not distinguishable from the improvements registered in adjacent CGM paddocks with moderate stocking rates. Dry 2012-2015 conditions in an environment that was already arid in the context of most HGM applications may have inhibited responses: Hawkins (2016) analyzed 103 studies of HGM and found no effect on plant basal cover or biomass where rainfall was $<500 \mathrm{~mm}$. Guanacos were also a complication in this study, but wild animals and drought are real-world factors that any grazing plan should take into account in Patagonia.

Degraded rangelands in Patagonia retained the capacity to regenerate using moderate, flexible stocking rates, under both types of management, and this is good news. HGM seems to be a safe option from the rangeland point of view, given that stocking is kept below grazing capacity. More benefits would probably arise from HGM rest periods in the long term, especially in wetlands or highly impacted areas. However, animal production issues have to be solved in order to sustain this type of management in a commercial station.

The Halliday family considers that difficulties sheep experienced may be the consequence of a long CGM history and that, over time, it would be possible to select animals that adapt more readily to these movements. They plan to reestablish rotation with better fences and water infrastructure, using forage supplements and smaller flocks with longer grazing periods during the perinatal stage, as shown in other Patagonian examples (Paruelo et al. 1992). 
Our study indicates that it is not realistic to expect fast regeneration by means of intense management in severely restricted habitats, such as the Magellan Steppes, but slow, persistent, long-term progress under careful management seems, on the other hand, feasible.

\section{Declaration of Competing Interest}

The authors declare that they have no known competing financial interests or personal relationships that could have appeared to influence the work reported in this paper.

\section{Acknowledgments}

Edward, Santiago, Teddy Halliday and Silvina Puig carried out the management. Pablo Sturzenbaum and Paola Imberti from OVIS participated in the HGM planning. Guillermo Clifton, Ariela Cesa, and Paola Vargas performed the animal condition scoring. Eugenia Vivar, Juan Carlos Kofalt, Cintia Schenkel, and Vanessa Torres took part in rangeland and/or guanaco populations monitoring. Pablo Borrelli analyzed the manuscript and suggested a number of changes, some of which were incorporated and others discussed with great benefit to the paper. Andres Cibils corrected an early version of the manuscript and helped to improve it considerably. Laura Laurenti from the Laboratorio de Inglés Científico (LaIC) service for the University of Patagonia reviewed and corrected the English. We also thank two anonymous reviewers who suggested a number of changes that improved the paper.

\section{Supplementary materials}

Supplementary material associated with this article can be found, in the online version, at doi:10.1016/j.rama.2020.09.006.

\section{References}

Abel, N.O., Blaikie, P., 1989. Land degradation, stocking rates and conservation policies in the communal rangelands of Botswana and Zimbabwe. Land Degradation \& Development 1, 101-123.

Aguiar, M.n.R. Sala, O.E., 1999. Patch structure, dynamics and implications for the functioning of arid ecosystems. Trends in Ecology \& Evolution 14, 273-277.

Anchorena, J., Cingolani, A., Livraghi, E., Collantes, M., Stoffella, S., 2001. Management of sheep grazing in Tierra del Fuego. Conicet-INTA, Buenos Aires, Argentina, p. 47.

Bertiller, M.B., Defossé, G.E., 1990. Clipping effects upon primary productivity and senescence: study case on Festuca pallescens (St Ives) Parodi in a Patagonian semiarid grassland, Argentina. Acta Oecologica 11, 79-92.

Bisigato, A.J., Bertiller, M., 1997. Grazing effects on patchy dryland vegetation in northern Patagonia. Journal of Arid Environments 36, 639-653.

Borrelli, P., 2001. Pastoral planning. In: Borrelli, P., Oliva, G. (Eds.), Sustainable sheep farming in Southern Patagonia. INTA, Buenos Aires, Argentina, pp. 183-196.

Borrelli, P., 2016. Regeneration of pastures and climate change. OVIS XXI, Buenos Aires, Argentina, p. 22

Borrelli, P. Oliva, G., 2001. Evaluación de pastizales. In: Borrelli, P., Oliva, G. (Eds.) Sustainable sheep farming in southern Patagonia:extensive management technology. INTA, Buenos Aires, pp. 163-168.

Briske, D.D., Derner, J.D., Brown, J.R., Fuhlendorf, S.D., Teague, W.R., Havstad, K.M. Gillen, R.L., Axh, A.J., Willms, W.D., 2008. Rotational grazing on rangelands: reconciliation of perception and experimental evidence. Rangeland Ecology \& Management 61, 3-17.

Buckland, S.T., Anderson, D.R., Burnham, K.P., Laake, J.L., 2005. Distance sampling. Wiley Online Library doi:10.1002/0470011815.b2a16019. Access date 19 October 2020.

Caldwell, M., Richards, J., Johnson, D., Nowak, R., Dzurec, R., 1981. Coping with herbivory: photosynthetic capacity and resource allocation in two semiarid Agropyron bunchgrasses. Oecologia 50, 14-24.

Cibils, A., Borrelli, P., 2005. Grasslands of Patagonia. In: Suttie, J.M., Reynolds, S.G., Batello, C. (Eds.), Grasslands of the world. Food and Agriculture Organization of the United Nations, Rome, Italy 121-170.

Cibils, A., Humano, G., Escalada, J., Torra, P., 2005. Primary productivity of a dry Magellanic Steppe grassland. In: González, L., Iglesias, R., Cibils, A. (Eds.), Campo experimental Potrok Aike. Result of 15 years of technical work. INTA, Buenos Aires, Argentina, p. 130.

Cibils, A.F., Fernández, R.J.L., 2014. Is holistic management really saving patagonian rangelands from degradation? A response to Teague. Rangelands Archives 36, $26-27$.
Coronato, F., 1999. Environmental impacts on offspring survival during the lambing period in central Patagonia. International Journal of Biometeorology 43, 113-118.

Cumming, K.J., 1989. Lehmann lovegrass and simple time control grazing. Rangelands 11 (4), 150-153.

Di Rienzo, J., Casanoves, F., Balzarini, M., Gonzalez, L., Tablada, M., ... Robledo, C. 2011. Grupo InfoStat InfoStat versión 2011. FCA, Universidad Nacional de Córdoba, Argentina.

du Toit, N.G.v., Snyman, H., Malan, P., 2009. Physical impact of grazing by sheep on soil parameters in the Nama Karoo subshrub/grass rangeland of South Africa. Journal of Arid Environments 73, 804-810.

Earl, J., Jones, C., 1996. The need for a new approach to grazing management-is cell grazing the answer. The Rangeland Journal 18, 327-350.

Faggi, A., 1985. Las comunidades vegetales de Rio Gallegos, Santa Cruz. In: Boelcke, O., Moore, D., Roig, F. (Eds.), Transecta Botany of Southern Patagonia. CONICET Patagonia Institute (Chile) Royal Society (Gran Bretaña), Buenos Aires, Argentina, pp. 592-633.

Fariña, C.M., Siffredi, G.L., Oesterheld, M., Cibils, A., Willems, P.M., 2018. Pastoreo intensivo en distintas estaciones del año: efectos a escala de comunidad en una estepa de Patagonia Norte. In: VIII National Congress - IV Mercosur Congress on Natural Grassland Management. Summaries and Talks, La Rioja. INTA, Chamical, p. 119.

Ferguson, B.G., Diemont, S.A., Alfaro-Arguello, R., Martin, J.F., Nahed-Toral, J., Álvarez-Solís, D., Pinto-Ruíz, R., 2013. Sustainability of holistic and conventional cattle ranching in the seasonally dry tropics of Chiapas, Mexico. Agricultural Systems 120, 38-48.

Golluscio, R., Deregibus, A., Paruelo, J., 1998. Sustainability and range managment in the Patagonian Steppes. Ecología Austral 8, 265-284.

Goodloe, S., 1969. Short duration grazing in Rhodesia. Journal of Range Management 22 (6) 369-373

Hawkins, H.-J., 2016. Does holistic planned grazing work in rangelands? A global meta-analysis. In: 10th International Rangeland Congress. Saskatoon, SK, p. 933 http://2016canada.rangelandcongress.org. Accessed 21/10/2020.

Heady, H., Child, R.D., 1994. Rangeland ecology and management.. Westview Press, Boulder, CO, USA, p. 519.

Heitschmidt, R., and Taylor Jr., C. 1991. Grazing management an ecological perspective.

Holechek, J., 1988. An approach for setting the stocking rate. Rangelands 10, 10-14

Holechek, J.L., Gomes, H., Molinar, F., Galt, D., Valdez, R., 2000. Short-duration grazing: the facts in 1999. Rangelands 22, 18-22.

Iglesias, R., Tapia, H., Alegre, B., Larrosa, J., Barría, D., 2005. Relación entre la condición corporal de la oveja al servicio y el número de corderos logrados a la señalada. In: González, L., Iglesias, R., Cibils, A. (Eds.), Campo Experimental Potrok Aike. Resultado de 15 años de labor técnica. Buenos Aires, INTA EEA Santa Cruz. pp. 81-82.

Jacobo, E.J., Rodríguez, A.M., Bartoloni, N., Deregibus, V.A., 2006. Rotational grazing effects on rangeland vegetation at a farm scale. Rangeland Ecology \& Management 59, 249-257.

Lara, A., Cruz, G. 1987. Assessment of the grazing potential of the agricultural are of the XII region, Magellan and Chilean Antarctica. INIA-Kampenaike Experimental Station, Punta Arenas. Chile.

Le Houérou, H., 1996. Climate change, drought and desertification. Journal of Arid Environments 34, 133-185.

Massy, C., 2014. A glass three-quarters full: regenerating native grassland landscape with holistic grazing management. Grass half full or grass half empty? Valuing native grassy landscapes Friends of Grasslands' Forum 30 October - 1 November 2014. CSIRO, Canberra Australia. http://www.fog.org.au/forum2014.htm.

McCosker, T., 2000. Cell crazing-the first 10 years in Australia. Tropical Grasslands 34, 207-218.

Merrill, L.B., 1954. A variation of deferred rotation grazing for use under southwest range conditions. Journal of Range Management 7, 752-754.

Naeth, M., Bailey, A., Pluth, D., Chanasyk, D., Hardin, R., 1991. Grazing impacts on litter and soil organic matter in mixed prairie and fescue grassland ecosystems of Alberta. Journal of Range Management 44, 7-12.

Norton, B.E., 2003. Spatial management of grazing to enhance both livestock production and resource condition: a scientific argument. In: Durban, South Africa: Proceedings of the VII International Rangeland Congress 810-820.

Noy-Meir, I., Gutman, M., Kaplan, Y., 1989. Responses of Mediterranean grassland plants to grazing and protection. The Journal of Ecology 290-310.

Oba, G., Vetaas, O.R., Stenseth, N.C., 2001. Relationships between biomass and plan species richness in arid-zone grazing lands. Journal of Applied Ecology 38, 836-845.

Oliva, G., Bran, D., Gaitán, J., Ferrante, D., Massara, V., Martínez, G.G., Adema, E. Enrique, M., Domínguez, E., Paredes, P., 2019a. Monitoring drylands: the MARAS system. Journal of Arid Environments 161, 55-63.

Oliva, G., Cibils, A., Borrelli, P., Humano, G., 1998. Stable states in relation to grazing in Patagonia: a 10-year experimental trial. Journal of Arid Environments 40 113-131.

Oliva, G., Collantes, M., Humano, G., 2005. Demography of grazed tussock populations in Patagonia. Rangeland Ecology \& Management 58, 466-473.

Oliva, G., Ferrante, D., Puig, S., Williams, M., 2012. Sustainable sheep management using continuous grazing and variable stocking rates in Patagonia: a case study The Rangeland Journal 34, 285-295.

Oliva, G., Paredes, P., Ferrante, D., Cepeda, C., Rabinovich, J., 2019b. Remotely sensed primary productivity shows that domestic and native herbivores combined are overgrazing Patagonia. Journal of Applied Ecology 56, 1575-1584. 
Paruelo, J.M., Golluscio, R.A., Deregibus, V.A., 1992. Manejo del pastoreo sobre bases ecológicas en la Patagonia extra andina: una experiencia a escala de establecimiento. Anales de la Sociedad Rural Argentina 126, 68-80.

Peel, M., Stalmans, M., 2018. The effect of Holistic Planned Grazing ${ }^{\mathrm{TM}}$ on African rangelands: a case study from Zimbabwe. African Journal of Range \& Forage Science 35, 23-31.

Posse, G., Anchorena, J., Collantes, M., 1996. Seasonal diets of sheep in the steppe region of Tierra del Fuego, Argentina. Journal of Range Management 49, 24-30.

Provenza, F., 2003. Foraging behavior: managing to survive in a world of change. Utah Agricultural Experiment Station.

Reynolds, J.F., Stafford Smith, D.M., Lambin, E.F., Turner II, B.L., Mortimore, M., Batterbury, S.P., Downing, T.E., Dowlatabadi, H., Fernández, R.J., Herrick, J.E., Huber-Sannwald, E., Jiang, H., Leemans, R., Lynam, T., Maestre, F.T., Ayarza, M., Walker, B., 2007. Global desertification: building a science for dryland development. Science 316, 847-851.

Roncoli, C., Jost, C., Perez, C., Moore, K., Ballo, A., Cissé, S., Ouattara, K., 2007. Carbon sequestration from common property resources: Lessons from community-based sustainable pasture management in north-central Mali. Agricultural Systems 94, 97-109.

Russel, A., Doney, J., Gunn, R.., 1969. Subjective assessment of body fat in live sheep. The Journal of Agricultural Science 72, 451-454

Sarasqueta, D. V. 2001. Breeding and Reproduction of Guanacos in Captivity Lama guanicoe. Rio Negro Province, Argentina: Patagonia Norte INTA Regional Center, EEA Bariloche, S.C. de Bariloche.

Savory, A., 1991. Holistic resource management: a conceptual framework for ecologially sound economic modelling. Ecological Economics 3, 181-191.

Savory, A., 2013. Response to request for information on the "science" and "methodology" underpinning holistic management and holistic planned grazing. Savory Institute. Available at: http://www.savoryinstitute.com. Access date:21/10/2020
Savory, A., 2018. Tools to manage ecosystem processes. Savory Institute, Boulder, CO, USA, p. 36.

Savory, A., Butterfield, J., 1999. Holistic management: a new framework for decision making. Island Press, New York, NY, USA.

Savory, A., Parson, S., 1980. The Savory grazing method. Rangelands 2, 234-237.

Soriano, A., 1956. Ecological and pasturial aspects of Patagonian vegetation related to its state and recoverability. Revista Argentina de Investigaciones Agrícolas 10, 349-372.

Stinner, D.H., Stinner, B.R., Martsolf, E., 1997. Biodiversity as an organizing principle in agroecosystem management: case studies of holistic resource management practitioners in the USA. Agriculture, Ecosystems \& Environment 62, 199-213.

Teague, R., Provenza, F., Kreuter, U., Steffens, T., Barnes, M., 2013. Multi-paddock grazing on rangelands: why the perceptual dichotomy between research results and rancher experience. Journal of Environmental Management 128, 699-717.

Teague, R., Provenza, F., Norton, B., Steffens, T., Barnes, M., Kothmann, M., Roath, R., 2008. Benefits of multi-paddock grazing management on rangelands: limitations of experimental grazing research and knowledge gaps. Grasslands: ecology, management and restoration. Nova Science Publishers, Hauppauge, NY, USA, pp. 41-80.

Teague, W., Dowhower, S., Baker, S., Haile, N., DeLaune, P., Conover, D., 2011. Grazing management impacts on vegetation, soil biota and soil chemical, physical and hydrological properties in tall grass prairie. Agriculture, Ecosystems \& Environment 141, 310-322.

Tongway, D., 1994. Rangeland soil condition assessment manual. CSIRO. Division of Wildlife and Ecology, Canberra, Australia.

Voisin, A., 1959. Grass productivity. Philosophical Library, New York, NY, USA, p. 353.

Weber, K., Gokhale, B., 2011. Effect of grazing on soil-water content in semiarid rangelands of southeast Idaho. Journal of Arid Environments 75, 464-470. 